\title{
Studi Adaptasi Ikan Seluang (Rasbora agryotaenia) Berdasarkan Tahap Domestikasi dari Perairan Sebangau
}

\author{
Study on Adaptation of Seluang Fish (Rasbora Agryotaenia) \\ Based on Domestication Stage \\ from Sebangau Water
}

\author{
Tania Serezova Augusta \\ Aquatic Aquaculture Studies Program Faculty of Fisheries Christian \\ University Palangka Raya \\ E-mail : taniaserezova@gmail.com
}

\begin{abstract}
This study aims to determine the adaptation of Seluang fish (Rasbora agryotaenia) based on the domestication stage of Sebangau waters. This research started in January until February 2018. The research method used is survey and experiment observation. The size of the tarpaulin pond used for domestication is $2 \times 3 \mathrm{~m}$, with a water height of $30 \mathrm{~cm}$. The number of fish sampled is 200 heads. Feed is given as much as $5 \%$ of the total weight of the fish kept, feeding done twice a day (morning and afternoon).

This domestication activity is still not perfect, because only part of the life cycle of fish (Rasbora agryotaenia) can be done in the cultivation system (survival and eating commercial feed). During maintenance activities, the amount of feed used was $63.840 \mathrm{~g}$ with the final weight of the fish was $16.905 \mathrm{~g}$. Survival rate (SR) of fish (Rasbora agryotaenia) during maintenance was $73.5 \%$ and deaths $26.5 \%$. From the calculation is known that the Feed Conversion Ratio (FCR) for fish (Rasbora agryotaenia) 2.8.

This domestication stage starts from the preparation of maintenance pools, fishing in nature, sorting, distribution and maintenance. During maintenance, five samples of sample fish were taken and five times the pool water quality measurement. From the five weights of the sample fish, it is known that the average weight of the fish is kept, $\mathrm{I}=0.003 \mathrm{~g}, \mathrm{II}=0.042$ $\mathrm{g}$, III $=0.051 \mathrm{~g}, \mathrm{IV}=0.082 \mathrm{~g}, \mathrm{~V}=0.115 \mathrm{~g}$. From the measurement of water quality of tarpaulin ponds it is known that the mean value of water quality parameters, for DO ranges from 1.5 to $8.8 \mathrm{mg} / \mathrm{L}$, the $\mathrm{pH}$ ranges from 5.5 to 7.2 and temperatures range from 27.4 to 27 , $70 \mathrm{C}$.
\end{abstract}

Keywords: Adaptation, Fish Seluang, Domestication

\begin{abstract}
Abstrak
Penelitian ini bertujuan untuk mengetahui adaptasi ikan Seluang (Rasbora agryotaenia) berdasarkan tahap domestikasi dari perairan Sebangau. Penelitian ini dimulai pada bulan Januari sampai dengan bulan Februari 2018. Metode penelitian yang digunakan adalah survei dan observasi eksperimen. Ukuran kolam terpal yang digunakan untuk domestikasi adalah $2 \mathrm{x}$ $3 \mathrm{~m}$, dengan ketinggian air $30 \mathrm{~cm}$. Jumlah ikan yang dijadikan sampel adalah 200 ekor. Pakan diberikan sebanyak $5 \%$ dari berat total ikan yang dipelihara, pemberian pakan dilakukan dua kali dalam sehari (pagi dan sore).

Kegiatan domestikasi ini masih belum sempurna, karena hanya sebagian daur hidup ikan seluang (Rasbora agryotaenia) yang dapat dilakukan dalam sistem budidaya (bertahan hidup dan memakan pakan komersil). Selama kegiatan pemeliharaan berlangsung, jumlah pakan yang digunakan adalah 63,840 $\mathrm{g}$ dengan berat akhir ikan adalah 16,905 g. Tingkat
\end{abstract}


kelangsungan hidup (SR) ikan seluang (Rasbora agryotaenia) selama pemeliharaan adalah 73,5\% dan kematian 26,5\%. Dari perhitungan diketahui bahwa Rasio Konversi Pakan (FCR) untuk ikan seluang (Rasbora agryotaenia) 2,8.

Tahapan domestikasi ini dimulai dari persiapan kolam pemeliharaan, penangkapan ikan di alam, penyortiran, penebaran dan pemeliharaan. Selama pemeliharaan, dilakukan lima kali penimbangan ikan sampel dan lima kali pengukuran kualitas air kolam. Dari lima kali penimbangan ikan sampel diketahui berat rata-rata ikan seluang yang dipelihara, $\mathrm{I}=0,003 \mathrm{~g}$, $\mathrm{II}=0,042 \mathrm{~g}, \mathrm{III}=0,051 \mathrm{~g}, \mathrm{IV}=0,082 \mathrm{~g}, \mathrm{~V}=0,115 \mathrm{~g}$. Dari pengukuran kualitas air kolam terpal diketahui bahwa nilai rata-rata parameter kualitas air, untuk DO berkisar antara $1,5-$ $8,8^{\mathrm{mg}} / \mathrm{L}, \mathrm{pH}$ berkisar antara $5,5-7,2$ dan suhu berkisar antara $27,4-27,7^{\circ} \mathrm{C}$.

Kata kunci : Adaptasi, Ikan Seluang, Domestikasi

\section{Pendahuluan}

Perairan Sebangau merupakan salah satu perairan yang menjadi tumpuan bagi masyarakat Kelurahan Kereng Bangkirai, karena dapat memberikan nilai ekonomi yang sangat penting bagi peningkatan kualitas hidup mereka (Anonim, 2013). Ikan-ikan di perairan ini memiliki kontribusi penting untuk kesejahteraan masyarakat terutama bagi para nelayan daratan di daerah perairan gambut, dan juga memiliki nilai ekonomis penting misalnya ikan seluang (Rasbora agryotaenia) yang merupakan salah satu sumber protein bagi masyarakat lokal (Page et al, 1998). Ikan seluang (Rasbora agryotaenia) adalah salah satu jenis ikan yang hidup di perairan tawar. Usaha penangkapan ikan seluang (Rasbora agryotaenia) sering dilakukan (Laporan statistik perikanan tangkap Provinsi Kalimantan Tengah tahun 2007 dan 2008), jika hal ini dilakukan terus-menerus (eksploitasi) akan menyebabkan langkanya keberadaan ikan seluang (Rasbora agryotaenia) di alam. Dalam jangka waktu yang lama usaha penangkapan yang tidak selektif dan dilakukan secara berlebihan akan dikhawatirkan terjadi penurunan jumlah untuk spesies ikan seluang (Rasbora agryotaenia) di alam. Salah satu upaya yang dapat dilakukan untuk menjaga kelestarian ikan seluang (Rasbora agryotaenia) adalah melalui kegiatan domestikasi dan budidaya untuk menghindari penurunan jumlah spesies ikan seluang di alam. Domestikasi ikan adalah kegiatan adaptasi ikan dari alam kedalam lingkungan dan makanan yang baru dan selanjutnya akan mengarah pada kegiatan budidaya dan konservasi (Kadarusman et al, 2007).

\section{Tujuan dan Manfaat}

Tujuan dari penelitian ini untuk mengetahui adaptasi ikan Seluang (Rasbora agryotaenia) berdasarkan tahap domestikasi dari perairan sebangau dalam wadah kolam terpal. 
Manfaat dari penelitian ini adalah memberikan informasi mengenai adaptasi ikan seluang (rasbora agryotaenia) berdasarkan tahap domestikasi dari perairan Sebangau dalam wadah kolam terpal dan menjaga kelestariannya di alam. Jenis alat tangkap yang digunakan untuk menangkap ikan seluang (Rasbora agryotaenia) di alam adalah ancau. Ikan hasil tangkapan dari perairan Sebangau di tampung dalam baskom atau ember. Sebelum ikan ditebarkan kedalam kolam pemeliharaan, dilakukan penyortiran menggunakan alat sortir manual yaitu saringan. Jumlah ikan yang akan dijadikan sampel dalam kegiatan domestikasi atau penelitian ini adalah 200 ekor.

Selama pemeliharaan, ikan seluang (Rasbora agryotaenia) diberi pakan primafeed nol (40\%) dengan pemberian pakan 5\% dari berat total ikan yang dipelihara. Pemberian pakan dilakukan 2 kali sehari (pagi dan sore hari).

\section{Analisis Data}

\section{Tingkat Kelangsungan Hidup}

Tingkat kelangsungan hidup (SR) merupakan persentase jumlah ikan hidup pada akhir pemeliharaan dibandingkan dengan jumlah ikan pada awal pemeliharaan yang dinyatakan dalam rumus Effendi (1979) :
$\mathrm{SR}=\frac{\mathrm{N}_{\mathrm{t}}}{\mathrm{N}_{\mathrm{o}}} \mathrm{X} 100 \%$

Keterangan:

$\mathrm{SR}=$ Survival rate $(\%)$

No $=$ Jumlah ikan pada awal penelitian (ekor)

$\mathrm{Nt}=$ Jumlah ikan pada akhir penelitian (ekor)

\section{Rasio Konversi Pakan (FCR)}

Rasio konversi pakan digunakan untuk mengetahui jumlah berat makanan yang dibutuhkan untuk pertumbuhan atau penambahan berat badan ikan (Effendi, 2004).

Rasio konversi pakan merupakan salah satu parameter yang digunakan untuk menggambarkan jumlah pakan yang dapat dimanfaatkan oleh ikan. Rasio konversi pakan (FCR) dapat dihitung berdasarkan rumus NRC (1977).

$\mathrm{FCR}=\frac{\mathrm{F}}{\mathrm{Wt}+\mathrm{D}}-\mathrm{W} 0$

Keterangan:

FCR = Rasio konversi pakan

$\mathrm{Wt}=$ Biomassa ikan pada akhir penelitian

$\mathrm{W} 0=$ Biomassa ikan pada awal penelitian

$\mathrm{F} \quad=\quad$ Pakan yang di konsumsi

$\mathrm{D}=\quad$ Biomassa ikan yang mati 
Mortalitas

MR $=\frac{\text { Jumlah ikanyang mati }}{\text { Jumlah ikan pada awal penelitian }}$

\section{Metode Penelitian}

Ikan sampel diambil pada bulan Januari-

Pebruari 2018 dari sungai Sebangau, dan

Tabel 1. Alat dan Bahan Dalam Penelitian kegiatan adaptasi dalam proses domestikasi ikan seluang (Rasbora agryotaenia) ini dilakukan di di Jalan. Sangga Buana II No. 1 Kota Palangka Raya.

\begin{tabular}{|l|l|l|}
\hline No & Alat/Bahan & Kegunaan \\
\hline 1. & Terpal Ukuran 2 x $3 \mathrm{~m}$ & Kolam pemeliharaaan \\
\hline 2. & Ikan seluang 200 ekor & Digunakan untuk ikan uji \\
\hline 3. & Air & Sebagai media untuk hidup ikan \\
\hline 4. & Prima feed 0 (40\%) & Untuk pakan ikan seluang \\
\hline 5. & Ancau & Digunakan untuk menangkap ikan di alam \\
\hline 6. & Timbangan Digital & Untuk menimbang berat ikan seluang \\
\hline 7. & Alat tulis & Untuk mencatat hasil penimbangan ikan seluang \\
\hline 8. & pH Meter & Untuk mengukur pH air di lapangan dan di kolam terpal \\
\hline 9. & Horiba Water Cheker & $\begin{array}{l}\text { Untuk mengukur suhu dan oksigen terlarut di lapangan dan } \\
\text { di kolam terpal }\end{array}$ \\
\hline 10. & Kamera & Untuk dokumentasi \\
\hline 11. & Ember/Baskm & Tempat menampung ikan hasil tangkapan \\
\hline 12. & Saringan/alat sortir & Digunakan untuk alat sortir \\
\hline
\end{tabular}

Persiapan kolam terpal yang berukuran $2 \times 3$ $\mathrm{m}$, dimana $1 \mathrm{~m}$ untuk ukuran lebar dan $2 \mathrm{~m}$ untuk ukuran panjang. Ketinggian air di dalam kolam terpal adalah $30 \mathrm{~cm}$, air yang digunakan untuk mengisi kolam terpal berasal dari sumur bor. Untuk saluran pengeluaran air menggunakan pipa yang berukuran $3 / 4$ inc dan untuk kemiringan dasar kolam terpal adalah $5 \mathrm{~mm}$, fungsi dari kemiringan ini yaitu untuk mempermudah dalam melakukan pergantian air dalam kolam terpal. 


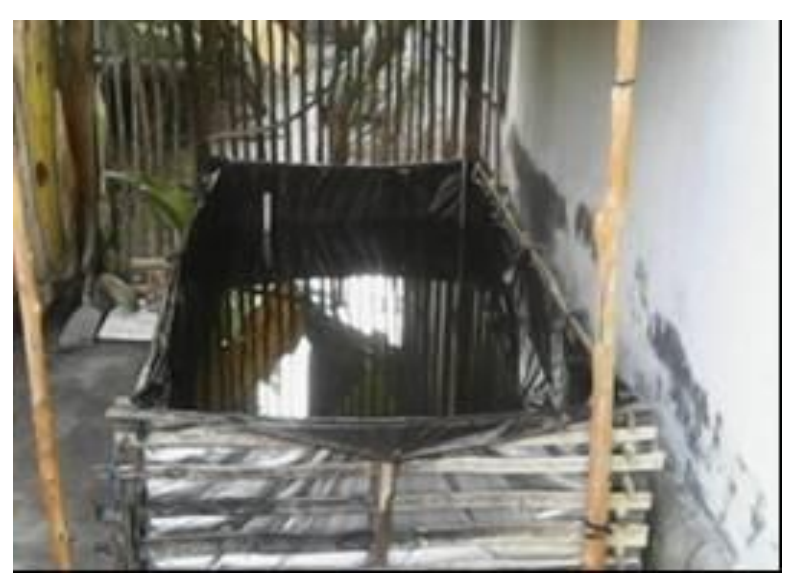

Gambar 1. Kolam Terpal Untuk Adaptasi Ikan Gambar

\section{HASIL DAN PEMBAHASAN}

Dalam penelitian dometikasi ikan Seluang (Rasbora agryotaenia) ini, tingkatan domestikasi yang dicapai yaitu belum sempurna. Domestikasi ikan seluang (Rasbora agryotaenia) dalam penelitian ini dikatakan belum sempurna, karena belum bisa dipijahkan dan tingkat keberhasilan pemijahannya masih belum bisa untuk diketahui. Hal ini disebabkan karena waktu pemeliharaan yang singkat yaitu hanya 2 bulan, dan waktu pemeliharaan untuk mencapai ukuran siap dipijahkan juga belum diketahui. Berdasarkan penelitian Lisna (2011), tentang Biologi Reproduksi Ikan Seluang (Rasbora argyrotaenia) di sungai Kumpeh Jambi diketahui bahwa ikan Seluang (Rasbora argyrotaenia) akan matang gonad setelah mencapai ukuran panjang di atas $30 \mathrm{~mm}$ dan berat di atas 7 gram. Pada penelitian Sulistiyarto (2012),

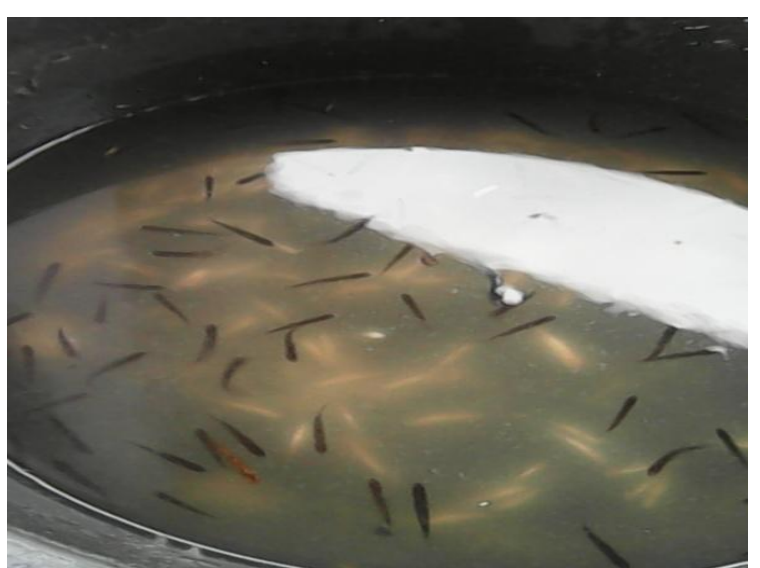

Gambar 2. Pemeliharaan Ikan Seluang di Kolam Terpal

diketahui bahwa panjang maksimum ikan Seluang (Rasbora agryotaenia) adalah 104 $\mathrm{mm}$, dan berat maksimum 13,6 gram.

\section{Kualitas Air Selama Penelitian}

a. Kualitas Air Sungai Sebangau

Pengukuran atau pengambilan kualitas air dari sungai Sebangau di lakukan pada empat lokasi yang berbeda yaitu, saluran irigasi Kelurahan Kereng Bangkirai, Sabaru, Parupuk Tunggal dan Rasau. Pengukuran kualitas air sungai Sebangau dilakukan satu kali dari setiap lokasi. Tujuan dari pengambilan kualitas air sungai Sebangau yaitu untuk mengetahui nilai parameter yang di ukur dan sebagai perbandingan untuk kualitas air kolam terpal yang digunakan untuk kegiatan domestikasi ikan Seluang (Rasbora agryotaenia). Adapun hasil dari pengukuran kualitas air sungai sebangau, dapat dilihat pada Tabel 2. 
Tabel 2. Nilai Parameter Kualitas Air Sungai Sebangau

\begin{tabular}{|c|c|c|c|c|c|c|}
\hline \multirow[b]{2}{*}{ No. } & \multirow[b]{2}{*}{$\begin{array}{c}\text { Parameter Kualitas } \\
\text { Air }\end{array}$} & \multicolumn{4}{|c|}{ Tempat Pengambilan Kualitas Air } & \multirow[b]{2}{*}{$\begin{array}{l}\text { Rata- } \\
\text { Rata }\end{array}$} \\
\hline & & $\begin{array}{c}\text { Saluran Irigasi } \\
\text { Kelurahan } \\
\text { Kereng Bangkirai }\end{array}$ & Sabaru & $\begin{array}{l}\text { Parupuk } \\
\text { Tunggal }\end{array}$ & Rasau & \\
\hline 1. & $\mathrm{DO}(\mathrm{mg} / \mathrm{L})$ & 2 & 2,6 & 2 & 7,5 & 3,5 \\
\hline 2. & $\mathrm{pH}$ & 6,7 & 3,6 & 3,34 & 4,34 & 4,4 \\
\hline 3. & Suhu (0C) & 31 & 31,3 & 31,3 & 31,5 & 31,7 \\
\hline
\end{tabular}

b. Kualitas Air Kolam Terpal

optimal bagi biota yang dipelihara.

Menurut Mulyanto (1992), bahwa Kondisi Kualitas air kolam

kondisi air sebagai media hidup biota air, harus disesuaikan dengan kondisi pemeliharaan ikan Seluang dapat dilihat pada Gambar 3 berikut .

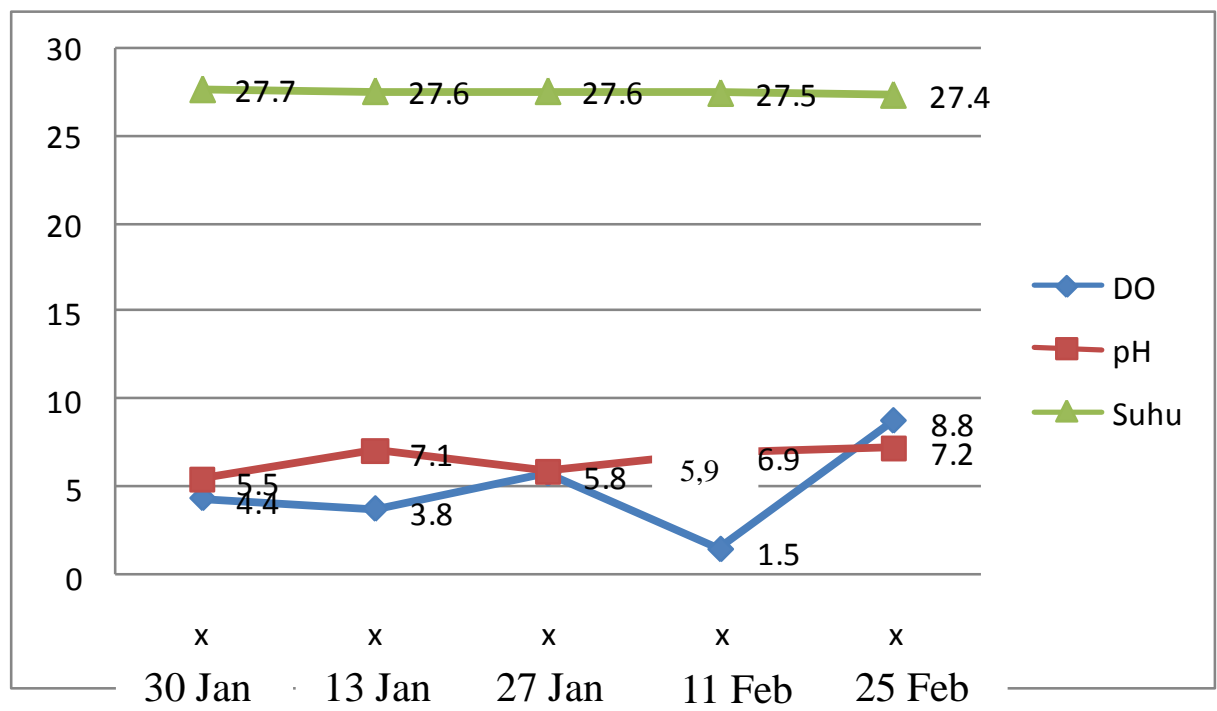

Gambar 3. Grafik Rata-rata DO, pH dan Suhu Selama Penelitian

Kandungan oksigen terlarut (DO) berdasarkan hasil pengukuran selama penelitiaan ditampilkan pada Gambar 2, menunjukkan bahwa pengukuran DO terendah terlihat pada tanggal 11 Feb dan DO tertinggi terlihat pada 25 Februari. Kisaran DO pada air kolam pemeliharaan ikan seluang adalah 1,5-8,8 mg/L. Pada saat DO air kolam mencapai angka 8,8 $\mathrm{mg} / \mathrm{L}$.

Menurut Barus (2002), menyatakan bahwa $\mathrm{pH}$ air yang ideal untuk organisme perairan berkisar antara 7-8,5 dan pada nilai ini pertumbuhan ikan optimal.

Hasil pengukuran $\mathrm{pH}$ air kolam selama penelitian berkisar antara 5,5-7,2. pH 5,5 menunjukkan bahwa air kolam bersifat 
asam dan $\mathrm{pH} 7,2$ netral. Menurunya $\mathrm{pH}$ air pada kolam pemeliharaan disebabkan oleh banyaknya jumlah $\mathrm{CO} 2$ yang terkandung dalam air kolam pemeliharaan sehingga $\mathrm{pH}$ air menurun (Wetzel, 1983). CO2 dalam air dihasilkan dari proses perombakan bahan organik oleh bakteri (Anonim, 2013).

Dari hasil penelitian, ditunjukkan bahwa kondisi suhu air kolam pemeliharaan ikan seluang (Rasbora agryotaenia) selama penelitian berkisar antara 27,4-27,7 0C. Dapat dikatakan bahwa suhu air kolam Tabel 3. Pemberian Pakan 5\% Untuk Ikan Seluang (Rasbora agryotaenia)

\begin{tabular}{|c|c|c|c|c|c|c|}
\hline $\begin{array}{l}\text { Sampling } \\
\mathrm{Ke}-\end{array}$ & $\begin{array}{l}\text { Padat } \\
\text { penebaran } \\
\text { setiap } \\
\text { sampling }\end{array}$ & $\begin{array}{l}\text { Berat rata- } \\
\text { rata ikan } \\
\text { seluang }(\mathrm{g})\end{array}$ & $\begin{array}{l}\text { Biomasa } \\
\text { ikan } \\
\text { seluang (g) }\end{array}$ & $\begin{array}{l}\text { Pemberian pakan } \\
5 \% \text { untuk sekali } \\
\text { makan per hari } \\
\text { (g) }\end{array}$ & $\begin{array}{l}\text { Pemberian pakan } \\
5 \% \text { untuk duakali } \\
\text { makan per hari } \\
\text { (g) }\end{array}$ & $\begin{array}{l}\text { Jumlah } \\
\text { Pakan yang } \\
\text { digunakan } \\
\text { dalam } \\
\text { setiap } 14 \\
\text { hari (g) }\end{array}$ \\
\hline I & 200 & 0,003 & 0,600 & 0,030 & 0,060 & 0,840 \\
\hline II & 180 & 0,042 & 7,560 & 0,370 & 0,740 & 10,360 \\
\hline III & 166 & 0,051 & 8,466 & 0,420 & 0,840 & 11,760 \\
\hline IV & 153 & 0,082 & 12,546 & 0,620 & 1,240 & 17,360 \\
\hline $\mathrm{V}$ & 147 & 0,115 & 16,905 & 0,840 & 1,680 & 23,520 \\
\hline Jumlah & & & & & & 63,840 \\
\hline
\end{tabular}

\section{Tingkat Kelangsungan Hidup (SR)}

a. Kelangsungan Hidup (SR)

Dari hasil perhitungan yang telah dilakukan diketahui bahwa SR untuk ikan Seluang selama 2 bulan pemeliharaan adalah $73,5 \%$, atau 147 ekor ikan Seluang yang mampu pemeliharaan ikan seluang tidak mengalami perubahan, karena masih berkisar di angka 27 0C. Ikan pelagis akan tumbuh optimal pada kisaran suhu 20-30 0C (Anonim, 2013).

Sampling atau penimbangan ikan peliharaan dilakukan 2 minggu sekali dengan penimbangan $25 \%$ dari jumlah padat tebar yang dilakukan. Selama pemeliharaan, pemberian pakan dilakukan sebanyak 5\% dari berat ikan yang dipelihara. 
Tingkat kematian ikan Seluang selama 2 bulan pemeliharaan adalah 26,5\%, atau 53 ekor ikan yang mati. Penyebab kematian ikan seluang yang dipelihara adalah, saat melakukan penimbangan dimana ikan Seluang ini selalu meloncat keluar dari mangkok timbangan sehingga menyebabkan ikan stres dan mati.

$$
\mathrm{MR}=\frac{\text { Jumlah ikanyang mati }}{\text { Jumlah ikan pada awal penelitian }}
$$
x $100 \%$

$$
\begin{aligned}
& =\frac{53}{200} \times 100 \% \\
& =26,5 \%
\end{aligned}
$$

\section{Rasio Konversi Pakan (FCR)}

Dari perhitungan yang telah dilakukan diketahui bahwa nilai FCR untuk pakan ikan seluang adalah 2,8. Atau 2,8 kg pakan yang dibutuhkan untuk menghasilkan $1 \mathrm{~kg}$ daging ikan Seluang (Rasbora agryotaenia).

$$
\begin{aligned}
& \text { FCR }=\frac{F}{W t+D}-\text { Wo } \\
& =\frac{63,840}{16,905+1,803}-0,600 \\
& =\frac{63,840}{18,708}-0,600 \\
& =3,446-0,600 \\
& =2,8
\end{aligned}
$$

\section{Kesimpulan}

Dari hasil penelitian yang telah dilakukan, diketahui bahwa domestikasi ikan Seluang (Rasbora agryotaenia) yang dilakukan adalah domestikasi belum sempurna. Dan bahwa adaptasi ikan Seluang (Rasbora agryotaenia) terhadap lingkungan dan makanan yang baru sangat cepat, dan toleransi terhadap perubahan parameter kualitas air DO, $\mathrm{pH}$ dan suhu cukup tinggi. Kisaran parameter kualitas air selama penelitian yaitu, DO 1,5-8,8 $\mathrm{mg} / \mathrm{L}, \mathrm{pH}$ 5,5-7,2 dan suhu 27,4-27,7 0C.

Dari hasil analisis data yang telah dilakukan diketahui bahwa kelangsungan hidup (SR) ikan Seluang (Rasbora agryotaenia) selama penelitian 73,5\% (147 ekor ikan yang hidup) dan mortalitas 26,5\% (53 ekor ikan yang mati). Rasio konversi pakan (FCR) 2,8 kg. Jumlah pakan yang digunakan selama 2 bulan pemeliharaan adalah 63,840 g. Pemberian pakan selama penelitian adalah $5 \%$, dengan pemberian pakan 2 kali sehari (pagi dan sore). Berat rata-rata ikan Seluang (Rasbora agryotaenia) pada akhir penelitian adalah $0,115 \mathrm{~g}$.pengerin

\section{Saran}

Adanya penelitian lanjutan dengan memperhatikan kualitas air yang layak dan melakukan penimbangan dengan cepat agar ikan tidak mati dan air yang digunakan tidak terlalu jernih (agak keruh) dan dikontrol dengan melakukan pergantian air. 


\section{DAFTAR PUSTAKA}

Anonim. 2013. Pengaruh pH Terhadap Perairan dan Organisme Perikanan. https://rakagilangandhika.wordpress.com/2 014/03/19/pengaru-ph-terhadap-perairandan-organisme-perikanan/. Diakses tanggal 12 Agustus 2016.

Anonim. 2013. Pengaruh Suhu, Salinitas, Arus, Cahaya, Dan Upwelling Terhadap Ikan.

http://alirohman11.blogspot.co.id/2013/03/ bab-i-pengaruh-suhu-salinitas-aruscahaya.html?m-1. Diakses tanggal 12 Agustus 2016.

Anonim. 2013. Taman Nasional Sebangau. http://amankdhay.blogspot.com/2013/04/m engenal-tn-sebangau.html. Diakses tanggal 3 April 2016.

Barus, T.A. 2002. Pengantar Limnologi Universitas Sumatera Utara. Medan.

Dinas Kelautan dan Perikanan Provinsi Kalimantan Tengah. Laporan Tahunan Statistik Perikanan Tangkap (Laporan
Hasil Survei Produksi Perikanan) 2007 2008.

Effendie, M. I. 1979. Metode Biologi Perikanan. Yayasan Dewi Sri Bogor. Bogor. Cetakan I. 112 Hal.

Lisna. 2011. Biologi Reproduksi Ikan Seluang (Rasbora argyrotaenia Blkr) Di Sungai Kumpeh Jambi. Program Pascasarjana Universitas Andalas Padang. (tidak di terbitkan).

Mulyanto. 1992. Lingkungan Hidup Untuk Ikan. Depdikbud, Jakarta.

NRC. 1977. Nutrition and Requirement of Warm Water Fishes. National Academic of Science Washington D.C.

Page, S.E. dan J.O. Rieley. 1998. Tropical Peatlands: a Rieview of Their Natural Resources Functions with Particular Reference to Southeast Asia

Sulistiyarto, B. 2012. Hubungan Panjang Berat, Faktor Kondisi, dan Komposisi Makanan Ikan Saluang (Rasbora argyrotaenia Blkr) di Dataran Banjir Sungai Rungan, Kalimantan Tengah. Fakultas Perikanan Universitas Kristen Palangka Raya. 